\title{
KEBUTUHAN KELUARGA PASIEN Critical Care Unit (CCU)
}

\author{
Repindra Oktari ${ }^{1}$, Hellena Deli ${ }^{2}$, Lita ${ }^{3)}$ \\ ${ }^{1}$ Program Studi Keperawatan STIKes Hang Tuah Pekanbaru, Yayasan HangTuah, Jl. \\ Mustafa Sari No.5, Tengkerang Sel., Kec. Bukit Raya, Kota Pekanbaru, Riau 28281 \\ email : Repindraoktaribbm@gmail.com \\ 2 Fakultas Ilmu Keperawatan Universitas Riau, Universitas Riau, J1. Pattimura, Cinta \\ Raja, Kec. Sail, Kota Pekanbaru, Riau 28127 \\ email : hellenadeli.hd@gmail.com \\ 3 Program Studi Keperawatan STIKes Hang Tuah Pekanbaru, Yayasan HangTuah, J1. \\ Mustafa Sari No.5, Tengkerang Sel., Kec. Bukit Raya, Kota Pekanbaru, Riau 28281 \\ email : lita@htp.ac.id
}

\begin{abstract}
The growing threat of patients' death will impact on their family's worry and stress which will negatively affect the role of the family as a part of the support system for the patient. The purpose of this study is to determine family needs of patients admitted to CCU of Arifin Achmad General Hospital of Riau Province. This is a quantitative study using descriptive design with 21 respondents chosen using consecutive sampling technique. The data were collected using questionnaire and then analyzed using univariate analysis. The study found that, regarding the need for service guarantees, $85.7 \%$ respondents stated that it was very important to understand the purpose of the medication and health treatment given to the patient; regarding the need for information, $66.7 \%$ respondents stated that it was very important to know the real condition of the patient; regarding the need for mental support from the family, $71.4 \%$ respondents stated that it was very important to have support from the family; regarding the need for convenience, $42.9 \%$ respondents stated that it was important and very important that they were provided with washroom close to the waiting room as well as the waiting room close to the intensive room; and regarding the need for closeness, 38.1\% respondents stated that it was very important to be able to visit the patient at CCU with one member of the family. It can be concluded that the need for understanding the purpose of the medication and health treatment given to the patient is the one that patients' family need the most. It is suggested that the nurses prioritize providing nursing care for the most needed family needs.
\end{abstract}

Key words: CCU, Family needs.

\section{Abstrak}

Besarnya ancaman kematian pasien akan memiliki dampak kecemasan dan stres keluarga dan berdampak pada peran keluarga sebagai support system menjadi tidak maksimal. Penelitian ini bertujuan untuk menggambarkan kebutuhan keluarga pasien CCU di RSUD Arifin Achmad Provinsi Riau. Jenis penelitian ini adalah kuantitatif dengan desain deskriptif, pengambilan sampel menggunakan teknik consecutive sampling, jumlah sampel dalam penelitian ini sebanyak 21 responden. Alat pengumpulan data menggunakan kuesioner dan analisis data dilakukan secara univariat. Hasil penelitian didapatkan pada kebutuhan jaminan pelayanan $85.7 \%$ responden menyatakan sangat penting untuk mengetahui tujuan pengobatan dan tindakan perawatan yang diberikan, pada kebutuhan informasi $66.7 \%$ responden menyatakan sangat penting mengetahui kondisi pasien yang sebenarnya, pada kebutuhan dukungan mental keluarga $71.4 \%$ responden menyatakan sangat penting mendapatkan dukungan antar keluarga, pada kebutuhan kenyamanan $42.9 \%$ responden menyatakan penting dan sangat penting untuk tersedia kamar mandi dekat ruang tunggu dan tersedia ruang tunggu didekat ruang intensif, serta pada kebutuhan kedekatan $38.1 \%$ responden menyatakan sangat penting untuk 
mengunjungi pasien diruang intensif (CCU) bersama salah satu kerabat. Dapat disimpulkan bahwa kebutuhan mengetahui tujuan pengobatan dan tindakan perawatan yang diberikan merupakan kebutuhan yang paling dibutuhkan keluarga. Kepada perawat disarankan untuk memprioritaskan asuhan keperawatan terhadap kebutuhan keluarga yang paling dibutuhkan.

Kata kunci : CCU, Kebutuhan keluarga.

\section{PENDAHULUAN}

Intensive care unit (ICU) adalah suatu bagian dari rumah sakit yang mandiri, dengan staf yang khusus dan perlengkapan yang khusus yang ditujukan untuk observasi, perawatan dan terapi pasien-pasien yang menderita penyakit akut, cedera atau penyulitpenyulit yang mengancam nyawa atau potensial mengancam nyawa dengan prognosis dubia yang diharapkan masih reversibel, dengan staf yang khusus dan perlengkapan yang khusus, menjadikan ICU tempat perawatan dengan biaya yang tergolong tinggi (Kementrian Kesehatan RI, 2011).

ICU mempunyai tanggung jawab untuk mempertahankan hidup dan menyembuhkan pasien, tetapi disisi lain kematian tidak dapat dihindari. Penelitian yang dilakukan Kabey AW; Kapend a Kalal L; Kilembe Manzanaza A (2017) , angka kematian di ICU rumah sakit universitas Lubumbashi, Republik Demokratik Kongo terdapat 198 meninggal, mewakili tingkat kematian $43,7 \%$ dari total 453 pasien ICU. Di Indonesia dari penelitian Hardisman, (2008) yang menyatakan, angka kematian di ICU RS M. Djamil Padang mencapai $25,6 \%$ dari 454 pasien yang di rawat.

Perhatian perawat di ruang ICU bertujuan pada tugas pokoknya seperti pengkajian terhadapat pasien, menegakkan diagnosa keperawatan, perencanaan keperawatan, intervensi dan evaluasi terhadap pasien di ICU (Kementrian Kesehatan RI, 2011).
Perhatian perawat tidak hanya diberikan kepada kebutuhan pasien yang dirawat tapi juga kepada kebutuhan keluarga pasien (Shorofi et al 2016) .

Menurut Fauziah \& Latipun, (2016), dengan adanya dukungan keluarga pasien akan merasa ada yang peduli terhadapnya, diperhatikan, merasa lebih percaya diri, tidak merasakan keputusasaan, tidak minder, bersemangat, bisa menerima kondisi diri, sehingga lebih tenang dalam menghadapi suatu masalah. Dukungan keluarga dalam bentuk sosial dapat membantu pasien karena dukungan sosial merupakan sesuatu yang diperlukan. Dukungan sosial dapat digunakan pada saat sakit atau dalam kesulitan lain, disinilah dukungan keluarga dapat membantu pasien untuk melalui waktu dengan cepat (Effendi \& Makhfudli, 2009).

Keluarga memiliki peran sebagai support system yang sangat penting dalam proses kesembuhan pasien, dengan tidak adanya dukungan keluarga yang diberikan kepada pasien maka akan sangat mempengaruhi proses kesembuhan dan pemulihan spritual pasien (Morton, Fontaine, Hudak, \& Gallo, 2013). Sering kali tindakan keperawatan yang dilakukan berfokus pada keadaan pasien dan kondisi keluarga akan terabaikan. Hal ini akan menghasilkan perasaan negatif yang melahirkan rasa cemas, stress dan depresi pada keluarga (Silva et al., 2017). ICU merupakan lokasi dengan 
tingkat stress tinggi dan penyakit kritis pada pasien dapat mempengaruhi keadaan anggota keluarga lainnya yang mengarah kepada perubahan negatif yang dapat menyebabkan stress dan krisis emosional pada keluarga (Shorofi et al 2016).

Kebutuhan keluarga diberikan untuk dapat memecahkan masalah tersebut, di ICU kebutuhan keluarga dapat terdiri dari kebutuhan akan kedekatan, jaminan pelayanan, dukungan mental, informasi dan kenyamanan (Molter \& Leske, 1995). Kebutuhan keluarga juga dapat dilihat dari sisi sebagai manusia yang holistik yang akan lengkap bila memiliki unsur biologis, psikologis, sosial dan spritual. Manusia juga bisa diartikan sebagai sistem yang memiliki komponen dari sistem adaptif, personal, interpersonal dan sosial (Rosmalawati, 2016).

Menurut (Atika \& Halimuddin, 2018), pentingnya jaminan pelayanan terhadap keluarga dalam mengetahui bahwa perawatan terbaik telah diberikan kepada pasien oleh profesional perawatan kesehatan yang menjadikan keluarga percaya diri serta mengurangi ketidakpastian dan stress keluarga. Pemberian informasi pada keluarga sangat penting, karena ketidaktahuan keluarga bisa menyebabkan kegelisahan, kebingungan, bahkan kecemasan, yang menjadikan informasi yang baik dapat mengurangi beban psikologis keluarga dan meningkatkan keefektifan perawatan. Kebutuhan keluarga untuk dekat dengan pasien dapat meningkatkan kepercayaan keluarga terhadap perawatan yang diberikan kepada pasien, dan mengurangi ketidaktahuan keluarga dengan kondisi pasien yang sebenarnya bila tidak dekat dengan pasien. Oleh karena itu keluarga membutuhkan perawat dan dokter sebagai perantara karena keluarga tidak bisa selalu di dekat pasien.

Salah satu rumah sakit di kota Semarang yang mengidentifikasikan kebutuhan keluarga terdapat hasil dari responden dengan nilai $96.3 \%$ menjadikan jaminan pelayanan sebagai kebutuhan paling penting diikuti oleh kebutuhan dekat dengan pasien $(86.4 \%)$, kebutuhan rasa nyaman (85.5\%), kebutuhan informasi $(79.8 \%)$ dan kebutuhan dukungan mental (72.3\%) (Saputra \& Utami, 2015). Sedangkan pada penelitian yang dilakukan oleh (Lukmanulhakim \& Firdaus, 2018), dalam mengidentifikasi pemenuhan kebutuhan keluarga didapatkan data bahwa informasi menempati posisi pertama dari 40 responden $65 \%$ diantaranya menyatakan sudah terpenuhi, diikuti oleh jaminan pelayanan $62.5 \%$, rasa nyaman $60 \%$, kedekatan dengan pasien $47.5 \%$ dan dukungan mental $42.5 \%$. Penelitian ini terlihat bahwa dukungan mental memiliki urutan terakhir dengan 57.5\% dari 40 reponden menyatakan belum terpenuhi.

Menurut hasil penelitian Herawati \& Fithriyani, (2018), keluarga yang menunggu pasien di ruang ICU mengalami kelelahan, keluhan tubuh serta gangguan tidur, terdapat juga rasa cemas, takut, sedih dan tegang. Jika dilihat dari respon sosial maka terlihat pengurangan dalam berkomunikasi serta adanya pengalaman baru.

Hasil studi pendahuluan yang dilakukan peneliti dengan wawancara pada 5 orang keluarga pasien yang menunggu pasien di ICU mengatakan bahwa jaminan pelayanan yang di berikan rumah sakit kepada pasien oleh petugas didalam tidak sesuai harapan keluarga yang mengharapkan pasien dapat diberikan perawatan terbaik. Keluarga 
juga mengatakan bahwa informasi yang disampaikan tidak diberikan secara langsung kepada keluarga dan keluarga menyebutkan bahwa pemberian informasi perubahan kondisi pasien hanya diberikan pada saat keadaan darurat dan keluarga merasakan bahwa jam berkunjung masih terasa kurang karena mereka ingin terus dekat dengan pasien. Dukungan mental pada keluarga yang diberikan petugas ICU juga masih kurang karena keluarga mengatakan bahwa petugas rumah sakit tidak maksimal dalam pemberian dukungan moral dengan kondisi keluarga yang menyatakan bahwa mereka merasa stress serta cemas serta keluarga mengatakan kurang nyaman atas fasilitas yang diberikan saat menunggu pasien dengan keadaan tempat tidur saat menunggu pasien. Hal-hal tersebut dapat mempengaruhi keluarga sebagai support system untuk pasien ICU. Melihat fenomena tersebut, peneliti ingin melakukan penelitian tentang "Gambaran Kebutuhan Keluarga pasien Critical Care Unit (CCU)".

METODELOGI PENELITIAN
Penelitian ini menggunakan jenis penelitian kuantitatif dengan desain deskriptif. Populasi pada penelitian ini adalah semua keluarga yang menunggu pasien intensive care unit (ICU) di Rumah Sakit Umum Daerah (RSUD) Arifin Achmad Provinsi Riau. Sampel dalam penelitian ini adalah keluarga yang bertanggung jawab untuk pasien intensive care unit (ICU) dan cardiovascular care unit (CVCU) di Rumah Sakit Umum Daerah (RSUD) Arifin Achmad Provinsi Riau berjumlah 21 responden. Pengambilan sampel pada penelitian ini menggunakan teknik consecutive sampling dengan alat pengumpulan data menggunakan lembar kuesioner. Variabel yang diteliti adalah gambaran kebutuhan keluarga pasien Critical care unit (CCU). Analisa data yang digunakan adalah analisis univariat.

\section{HASIL PENELITIAN}

Hasil penelitian yang dilakukan dari bulan Juli-Agustus 2019 di ruang ICU dan CVCU RSUD Arifin Achmad Provinsi Riau pada 21 responden dengan data yang diperoleh sebagai berikut:

\section{A. Karakteristik Responden}

Tabel 1. Distribusi frekuensi jenis kelamin, usia, hubungan dengan pasien pengalaman CCU sebelumnya, dan tempat tinggal.

\begin{tabular}{lllcc}
\hline No & $\begin{array}{c}\text { Klasifikasi karakteristik } \\
\text { responden }\end{array}$ & Karakteristik responden & $\mathrm{f}$ & $\%$ \\
\hline 1 & Jenis kelamin & Laki-laki & 15 & 71.4 \\
& & Perempuan & 6 & 28.6 \\
\hline \multirow{3}{*}{2} & Usia & Massa remaja akhir (17-25) & 1 & 4.8 \\
& & Massa dewasa awal (26-35) & 9 & 42.9 \\
& & Massa dewasa akhir (36-45) & 7 & 33.3 \\
& & Massa lansia awal (46-55) & 2 & 9.5 \\
& & Massa lansia akhir (56-65) & 2 & 9.5 \\
\hline & & Orang tua & 4 & 19.0
\end{tabular}


3 Hubungan dengan pasien $\quad$ Anak $\quad 6 \quad 28.6$

\begin{tabular}{|c|c|c|c|c|}
\hline & & $\begin{array}{l}\text { Saudara } \\
\text { Suami/Istri }\end{array}$ & 9 & $\begin{array}{c}42.9 \\
9.5\end{array}$ \\
\hline \multirow[t]{2}{*}{4} & Pengalaman CCU sebelumnya & Pernah & 8 & 38.1 \\
\hline & & Tidak pernah & 13 & 61.9 \\
\hline \multirow{9}{*}{5} & \multirow{9}{*}{ Tempat tinggal } & Pekanbaru & 10 & 47.6 \\
\hline & & Kuantan singingi & 1 & 4.8 \\
\hline & & Siak & 3 & 14.3 \\
\hline & & Pariaman & 1 & 4.8 \\
\hline & & Pasaman & 1 & 4.8 \\
\hline & & Rokan hilir & 1 & 4.8 \\
\hline & & Dumai & 3 & 14.3 \\
\hline & & Kerinci & 1 & 4.8 \\
\hline & & Total & 21 & 100 \\
\hline
\end{tabular}

Berdasarkan tabel 1. diperoleh hasil bahwa sebagian besar reponden berjenis kelamin laki-laki sebanyak $71.4 \%$, dengan jumlah usia terbanyak pada kategori usia massa dewasa awal 26-35 tahun sebanyak $42.9 \%$, hubungan dengan pasien sebagai saudara sebanyak
$42.9 \%$, pengalaman CCU sebelumnya sebagian besar tidak memiliki pengalaman di CCU sebanyak $61.9 \%$, dan tempat tinggal responden sebagian besar tinggal di kota Pekanbaru sebanyak $47.6 \%$.

\section{B. Gambaran Kebutuhan Keluarga Pasien Critical care unit (CCU)}

Tabel 2. Gambaran Kebutuhan Keluarga Akan Jaminan Pelayanan

\begin{tabular}{|c|c|c|c|c|c|c|c|c|c|c|c|}
\hline \multirow[t]{2}{*}{ No } & \multirow[t]{2}{*}{ Variabel } & \multicolumn{2}{|c|}{$\begin{array}{c}\text { Tidak } \\
\text { penting }\end{array}$} & \multicolumn{2}{|c|}{$\begin{array}{c}\text { Sedikit } \\
\text { penting }\end{array}$} & \multicolumn{2}{|c|}{ Penting } & \multicolumn{2}{|c|}{$\begin{array}{l}\text { Sangat } \\
\text { penting }\end{array}$} & \multicolumn{2}{|c|}{ Total } \\
\hline & & f & $\%$ & $\mathbf{f}$ & $\%$ & f & $\%$ & f & $\%$ & f & $\%$ \\
\hline 1 & $\begin{array}{l}\text { Mengetahui tujuan pengobatan } \\
\text { dan tindakan perawatan yang } \\
\text { diberikan }\end{array}$ & 1 & 4.8 & 1 & 4.8 & 1 & 4.8 & 19 & $\begin{array}{l}85 . \\
7\end{array}$ & 21 & 100 \\
\hline 2 & $\begin{array}{l}\text { Berdiskusi dengan dokter setiap } \\
\text { hari }\end{array}$ & 0 & 0 & 2 & 9.5 & 9 & $\begin{array}{l}42 . \\
9\end{array}$ & 10 & $\begin{array}{l}47 . \\
6\end{array}$ & 21 & 100 \\
\hline 3 & $\begin{array}{l}\text { Terdapat tenaga kesehatan yang } \\
\text { dapat dihubungi, ketika tidak } \\
\text { ada keluarga yang menunggu di } \\
\text { rumah sakit }\end{array}$ & 2 & 9.5 & 1 & 4.8 & 11 & $\begin{array}{l}52 . \\
4\end{array}$ & 7 & $\begin{array}{l}33 . \\
3\end{array}$ & 21 & 100 \\
\hline 4 & $\begin{array}{l}\text { Memiliki harapan untuk } \\
\text { kesembuhan pasien }\end{array}$ & 0 & 0 & 2 & 9.5 & 4 & $\begin{array}{l}19 . \\
0\end{array}$ & 15 & $\begin{array}{l}71 . \\
4\end{array}$ & 21 & 100 \\
\hline 5 & $\begin{array}{l}\text { Memperoleh jaminan bahwa } \\
\text { pasien mendapatkan perawatan } \\
\text { yang baik }\end{array}$ & 0 & 0 & 2 & 9.5 & 5 & $\begin{array}{l}23 . \\
8\end{array}$ & 14 & $\begin{array}{l}66 . \\
7\end{array}$ & 21 & 100 \\
\hline 6 & $\begin{array}{l}\text { Mendapatkan jaminan dari } \\
\text { tenaga kesehatan bahwa semua } \\
\text { akan baik-baik saja ketika Anda } \\
\text { meninggalkan rumah sakit } \\
\text { sebentar }\end{array}$ & 0 & 0 & 2 & 9.5 & 7 & 33. & 12 & $\begin{array}{l}57 . \\
1\end{array}$ & 21 & 100 \\
\hline
\end{tabular}




\begin{tabular}{lllllllllllll}
\hline 7 & $\begin{array}{l}\text { Dapat berdiskusi } \begin{array}{l}\text { dengan } \\
\text { perawat mengenai } \\
\text { pasien }\end{array} \\
\text { kondisi }\end{array}$ & & 0 & 2 & 9.5 & 10 & $\begin{array}{l}47 . \\
6\end{array}$ & 9 & $\begin{array}{l}42 . \\
9\end{array}$ & 21 & 100 \\
\hline 8 & $\begin{array}{l}\text { Mendapatkan waktu } \\
\text { yang tepat }\end{array}$ & kunjung & 0 & 0 & 6 & $\begin{array}{l}28 . \\
6\end{array}$ & 6 & $\begin{array}{l}28 . \\
6\end{array}$ & 9 & $\begin{array}{l}42 . \\
9\end{array}$ & 21 & 100 \\
\hline 9 & $\begin{array}{l}\text { Berdiskusi tentang } \\
\text { rujukan pasien }\end{array}$ & rencana & 0 & 0 & 5 & $\begin{array}{l}23 . \\
8\end{array}$ & 9 & $\begin{array}{l}42 . \\
9\end{array}$ & & 33. & 21 & 100 \\
\end{tabular}

Tabel 2. diperoleh hasil bahwa "Mengetahui tujuan pengobatan dan kebutuhan keluarga akan jaminan tindakan perawatan yang diberikan".

pelayanan adalah $85.7 \%$ responden

menyatakan sangat penting untuk

Tabel 3. Gambaran Kebutuhan Keluarga Akan Informasi

\begin{tabular}{|c|c|c|c|c|c|c|c|c|c|c|c|}
\hline \multirow[t]{2}{*}{ No } & \multirow[t]{2}{*}{ Variabel } & \multicolumn{2}{|c|}{$\begin{array}{c}\text { Tidak } \\
\text { penting }\end{array}$} & \multicolumn{2}{|c|}{$\begin{array}{l}\text { Sedikit } \\
\text { penting }\end{array}$} & \multicolumn{2}{|c|}{ Penting } & \multicolumn{2}{|c|}{$\begin{array}{l}\text { Sangat } \\
\text { penting }\end{array}$} & \multicolumn{2}{|c|}{ Total } \\
\hline & & f & $\%$ & $f$ & $\%$ & f & $\%$ & f & $\%$ & f & $\%$ \\
\hline 1 & $\begin{array}{l}\text { Mendapatkan penjelasan tentang } \\
\text { situasi / kondisi di ruang } \\
\text { perawatan intensif } \\
\text { masuk ke CCU untuk pertama } \\
\text { kali }\end{array}$ & 1 & 4.8 & 1 & 4.8 & 9 & 42.9 & 10 & 47.6 & 21 & 100 \\
\hline 2 & $\begin{array}{l}\text { Mengetahui petugas rumah sakit } \\
\text { yang dapat memberikan informasi }\end{array}$ & 0 & 0 & 1 & 4.8 & 11 & 52.4 & 9 & 42.9 & 21 & 100 \\
\hline 3 & $\begin{array}{l}\text { Mengetahui petugas rumah sakit } \\
\text { yang merawat pasien }\end{array}$ & 1 & 4.8 & 2 & 9.5 & 9 & 42.9 & 9 & 42.9 & 21 & 100 \\
\hline 4 & $\begin{array}{l}\text { Mengetahui bagaimana pasien } \\
\text { mendapatkan pengobatan }\end{array}$ & 0 & 0 & 2 & 9.5 & 6 & 28.6 & 13 & 61.9 & 21 & 100 \\
\hline 5 & $\begin{array}{l}\text { Mengetahui secara rinci tindakan } \\
\text { yang dilakukan tenaga kesehatan } \\
\text { pada pasien }\end{array}$ & 1 & 4.8 & 1 & 4.8 & 9 & 42.9 & 10 & 47.6 & 21 & 100 \\
\hline 6 & $\begin{array}{lc}\text { Tenaga } & \text { kesehatan } \\
\text { menginformasikan } & \text { tentang } \\
\text { kemungkinan kematian pasien }\end{array}$ & 2 & 9.5 & 4 & 19.0 & 8 & 38.1 & 7 & 33.3 & 21 & 100 \\
\hline 7 & $\begin{array}{l}\text { Diberikan penjelasan pada } \\
\text { informasi yang tidak dimengerti }\end{array}$ & 1 & 4.8 & 3 & 14.3 & 9 & 42.9 & 8 & 38.1 & 21 & 100 \\
\hline 8 & $\begin{array}{l}\text { Menghubungi keluarga apabila } \\
\text { ada perubahan pada kondisi } \\
\text { pasien }\end{array}$ & 0 & 0 & 3 & 14.3 & 5 & 23.8 & 13 & 61.9 & 21 & 100 \\
\hline 9 & $\begin{array}{l}\text { Mendapatkan informasi tentang } \\
\text { kondisi pasien setidaknya sekali } \\
\text { sehari }\end{array}$ & 0 & 0 & 1 & 4.8 & 10 & 47.6 & 10 & 47.6 & 21 & 100 \\
\hline 10 & $\begin{array}{l}\text { Mengetahui kondisi pasien yang } \\
\text { sebenarnya }\end{array}$ & 0 & 0 & 2 & 9.5 & 5 & 23.8 & 14 & 66.7 & 21 & 100 \\
\hline
\end{tabular}

Tabel 3. diperoleh hasil bahwa kebutuhan keluarga akan infromasi adalah $66.7 \%$ responden menyatakan sangat penting untuk "Mengetahui kondisi pasien yang sebenarnya". 
Tabel 4. Gambaran Kebutuhan Keluarga Akan Dukungan Mental Keluarga

\begin{tabular}{|c|c|c|c|c|c|c|c|c|c|c|c|}
\hline \multirow[t]{2}{*}{ No } & \multirow[t]{2}{*}{ Variabel } & \multirow{2}{*}{$\begin{array}{c}\text { Tidak } \\
\text { penting }\end{array}$} & \multicolumn{2}{|c|}{$\begin{array}{l}\text { Sedikit } \\
\text { penting }\end{array}$} & \multicolumn{3}{|c|}{ Penting } & \multicolumn{2}{|c|}{$\begin{array}{l}\text { Sangat } \\
\text { penting }\end{array}$} & \multicolumn{2}{|c|}{ Total } \\
\hline & & & $\%$ & f & $\%$ & f & $\%$ & f & $\%$ & f & $\%$ \\
\hline 1 & $\begin{array}{ll}\text { Mendapatkan } & \text { dukungan } \\
\text { antar keluarga } & \end{array}$ & 1 & 4.8 & 2 & 9.5 & 3 & 14.3 & 15 & 71.4 & 21 & 100 \\
\hline 2 & $\begin{array}{l}\text { Merasa kehadirannya } \\
\text { diterima oleh petugas rumah } \\
\text { sakit }\end{array}$ & 1 & 4.8 & 2 & 9.5 & 10 & 47.6 & 8 & 38.1 & 21 & 100 \\
\hline 3 & $\begin{array}{l}\text { Memiliki kerabat yang dapat } \\
\text { membantu terkait masalah } \\
\text { keuangan }\end{array}$ & 1 & 4.8 & 4 & 19.0 & 9 & 42.9 & 7 & 33.3 & 21 & 100 \\
\hline 4 & $\begin{array}{l}\text { Disediakan tokoh agama } \\
\text { (misal: kyai/pendeta) untuk } \\
\text { mendampingi }\end{array}$ & 7 & 33.3 & 2 & 9.5 & 5 & 23.8 & 7 & 33.3 & 21 & 100 \\
\hline 5 & $\begin{array}{l}\text { Mempunyai kerabat yang } \\
\text { peduli dengan kesehatan } \\
\text { Anda }\end{array}$ & 2 & 9.5 & 3 & 14.3 & 8 & 38.1 & 8 & 38.1 & 21 & 100 \\
\hline 6 & $\begin{array}{l}\text { Berdiskusi dengan orang } \\
\text { lain mengenai masalah yang } \\
\text { dihadapi }\end{array}$ & 4 & 19.0 & 5 & 23.8 & 8 & 38.1 & 4 & 19.0 & 21 & 100 \\
\hline 7 & $\begin{array}{l}\text { Mempunyai kerabat yang } \\
\text { dapat diajak berbagi cerita } \\
\text { tentang masalah yang } \\
\text { dialami }\end{array}$ & 2 & 9.5 & 4 & 19.0 & 8 & 38.1 & 7 & 33.3 & 21 & 100 \\
\hline 8 & $\begin{array}{l}\text { Berdiskusi tentang } \\
\text { kebutuhan rohani dengan } \\
\text { tokoh agama (misal: } \\
\text { rohaniawan atau pendeta) }\end{array}$ & 4 & 19.0 & 6 & 28.6 & 6 & 28.6 & 5 & 23.8 & 21 & 100 \\
\hline 9 & $\begin{array}{l}\text { Merasakan bahwa staf } \\
\text { rumah sakit peduli kepada } \\
\text { pasien }\end{array}$ & 0 & 0 & 2 & 9.5 & 10 & 47.6 & 9 & 42.9 & 21 & 100 \\
\hline & $\begin{array}{l}\text { Tabel } 4.4 \text { diperoleh has } \\
\text { kebutuhan keluarga akan } \\
\text { mental keluarga adalah }\end{array}$ & $\begin{array}{r}\text { bahwa } \\
\text { ukungan } \\
71.4 \%\end{array}$ & & & $\mathbf{n}$ & & Ka & 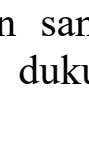 & an & $\begin{array}{l}\text { ing } \\
\text { itar }\end{array}$ & \\
\hline
\end{tabular}

Tabel 5. Gambaran Kebutuhan Keluarga Akan Kenyamanan

\begin{tabular}{|c|c|c|c|c|c|c|c|c|c|c|c|}
\hline \multirow[t]{2}{*}{ No } & \multirow[t]{2}{*}{ Variabel } & \multicolumn{2}{|c|}{$\begin{array}{c}\text { Tidak } \\
\text { penting }\end{array}$} & \multicolumn{2}{|c|}{$\begin{array}{l}\text { Sedikit } \\
\text { penting }\end{array}$} & \multicolumn{2}{|c|}{ Penting } & \multicolumn{2}{|c|}{$\begin{array}{l}\text { Sangat } \\
\text { penting }\end{array}$} & \multicolumn{2}{|c|}{ Total } \\
\hline & & f & $\%$ & f & $\%$ & f & $\%$ & f & $\%$ & $\mathbf{f}$ & $\%$ \\
\hline 1 & $\begin{array}{l}\text { Dapat mengungkapkan setiap } \\
\text { perasaan yang dirasakan }\end{array}$ & 1 & 4.8 & 6 & 28.6 & 9 & 42.9 & 5 & 23.8 & 21 & 100 \\
\hline 2 & Diperbolehkan untuk menangis & 7 & 33.3 & 6 & 28.6 & 5 & 23.8 & 3 & 14.3 & 21 & 100 \\
\hline 3 & $\begin{array}{l}\text { Tersedia kamar mandi dekat ruang } \\
\text { tunggu }\end{array}$ & 0 & 0 & 3 & 14.3 & 9 & 42.9 & 9 & 42.9 & 21 & 100 \\
\hline 4 & $\begin{array}{l}\text { Tersedia ruang tunggu didekat ruang } \\
\text { intensif }\end{array}$ & 0 & 0 & 3 & 14.3 & 9 & 42.9 & 9 & 42.9 & 21 & 100 \\
\hline
\end{tabular}


Tabel 4.5 diperoleh hasil bahwa kebutuhan keluarga akan kenyamanan adalah $42.9 \%$ responden menyatakan penting dan sangat penting untuk
"Tersedia kamar mandi dekat ruang tunggu" dan "Tersedia ruang tunggu didekat ruang intensif".

Tabel 6. Gambaran Kebutuhan Keluarga Akan Kedekatan

\begin{tabular}{|c|c|c|c|c|c|c|c|c|c|c|c|}
\hline \multirow[t]{2}{*}{ No } & \multirow[t]{2}{*}{ Variabel } & \multicolumn{2}{|c|}{ Tidak penting } & \multicolumn{2}{|c|}{$\begin{array}{l}\text { Sedikit } \\
\text { penting }\end{array}$} & \multicolumn{2}{|c|}{ Penting } & \multicolumn{2}{|c|}{$\begin{array}{l}\text { Sangat } \\
\text { penting }\end{array}$} & \multicolumn{2}{|c|}{ Total } \\
\hline & & f & $\%$ & f & $\%$ & f & $\%$ & f & $\%$ & $\mathbf{f}$ & $\%$ \\
\hline 1 & $\begin{array}{l}\text { Ada waktu kunjungan } \\
\text { tambahan saat kondisi } \\
\text { tertentu }\end{array}$ & 0 & 0 & 3 & 14.3 & 11 & 52.4 & 7 & 33.3 & 21 & $\begin{array}{c}10 \\
0\end{array}$ \\
\hline 2 & $\begin{array}{l}\text { Dapat mengunjungi } \\
\text { pasien setiap saat }\end{array}$ & 1 & 4.8 & 5 & 23.8 & 10 & 47.6 & 5 & 23.8 & 21 & $\begin{array}{c}10 \\
0\end{array}$ \\
\hline 3 & 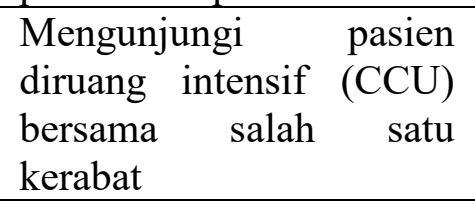 & 1 & 4.8 & 5 & 23.8 & 7 & 33.3 & 8 & 38.1 & 21 & $\begin{array}{c}10 \\
0\end{array}$ \\
\hline 4 & $\begin{array}{l}\text { Dapat mengunjungi } \\
\text { pasien sesering mungkin }\end{array}$ & 2 & 9.5 & 9 & 42.9 & 6 & 28.6 & 4 & 19.0 & 21 & $\begin{array}{c}10 \\
0\end{array}$ \\
\hline
\end{tabular}

Tabel 6. diperoleh hasil bahwa kebutuhan keluarga akan kedekatan adalah 38.1\% responden menyatakan sangat penting untuk "Mengunjungi pasien diruang intensif (CCU) bersama salah satu kerabat".

\section{PEMBAHASAN}

\section{A. Karakteristik responden}

Berdasarkan hasil penelitian diperoleh bahwa sebagian besar reponden berjenis kelamin laki-laki sebanyak $71.4 \%$, dengan jumlah usia terbanyak pada kategori usia massa dewasa awal 26-35 tahun sebanyak $42.9 \%$, hubungan dengan pasien sebagai saudara sebanyak $42.9 \%$, pengalaman $\mathrm{CCU}$ sebelumnya sebagian besar tidak memiliki pengalaman di CCU sebanyak $61.9 \%$, dan tempat tinggal responden sebagian besar tinggal di kota Pekanbaru sebanyak $47.6 \%$.

Menurut Nasir dan Muhith (2011), kategori dewasa muda pada usia $20-40$ tahun ciri-ciri perkembangan sebagai berikut: gaya hidup personal berkembang, mulai pembinaan hidup dengan orang lain, sudah memiliki komitmen dan kemampuan, individu berusaha mencapai dan menguasai dunia dengan kebiasaan berpikir rasional meningkat, dan pengalaman kehidupan, pendidikan serta kesempatan kerja mengalami peningkatan.

Menurut Saam dan Wahyuni (2014), keberhasilan perkembangan pada periode masa dewasa awal dengan usia 19-35 tahun akan menghasilkan rasa cinta dan kasih sayang. Cinta merupakan kemampuan untuk mengesampingkan segala bentuk perbedaan dan keangkuhan melalui rasa saling membutuhkan rasa cinta mencakup hubungan dengan kekasih, orang tua, sahabat dan kerabat. Kasih sayang terwujud dalam ikatan perkawinan akan berfungsi sebagai perkawinan yang memuaskan setiap pasangan. Menurut Irwanto, dkk (2002), periode dewasa awal usia 18-40 tahun perkembangan yang terjadi ialah umur 
pematapan dan penyesuaian terhadap pola hidup baru. Pada usia ini mulai belajar berbagai peranan yang sudah menetap seperti: sebagai orang tua, sebagai guru, pemuka masyarakat, termasuk sebagai laki-laki dewasa dan wanita dewasa.

Periode dewasa awal terjadi penetapan peranan sebagai laki-laki dewasa dan wanita dewasa serta mendapatkan peningkatan berpikir secara rasional sehingga memudahkan dalam mengambil keputusan yang terbaik untuk pasien. Periode ini juga memperoleh rasa cinta dan kasih sayang, rasa cinta dapat diberikan kepada untuk kekasih, keluarga dan sahabat. Rasa sayang dapat diwujudkan dalam ikatan perkawinan. Hasil yang didapat saudara/kerabat yang menunggu pasien lebih banyak sehingga peran rasa cinta dapat direalisasikan. Tempat tinggal dikota Pekanbaru memudahkan akses untuk keluarga yang menunggu pasien sehingga tidak memberatkan masalah keungan keluarga untuk akses kerumah sakit.

\section{B. Gambaran Kebutuhan Keluarga Pasien Critical care unit (CCU)}

\section{Kebutuhan keluarga akan jaminan pelayanan}

Berdasarkan penelitian ini kebutuhan jaminan pelayanan, diperolehan hasil tertinggi pada jaminan pelayanan adalah kebutuhan keluarga untuk "mengetahui tujuan pengobatan dan tindakan perawatan yang diberikan" dengan perolehan $85.7 \%$ responden menyatakan sangat penting dari 21 responden. Sejalan dengan penelitian Saputra dan Utami (2018), menyatakan dari 54 responden terdapat $61.1 \%$ responden menyatakan kebutuhan "mengetahui alasan kenapa suatu tindakan dilakukan terhadap pasien" sangat penting, sedangkan penelitian yang dilakukan oleh Dharmalingam et al., (2016), terdapat 60 responden yang berpartisipasi menyatakan "To know the expected outcome" sebagai kebutuhan yang menepati urutan ke-3 dari 45 variabel yang tersedia dengan mean 3.78 menyatakan kebutuhan tersebut sangat penting.

Perolehan tersebut sejalan dengan Bustami (2012), menyatakan bahwa yang mempengaruhi kualitas mutu pelayanan kesehatan adalah daya tanggap yang berisi karyawan/staf membantu semua pelanggan serta berkeinginan dan melakukan pemberian pelayanan dengan tanggap, baik itu sikap dari penyedia jasa yang penuh perhatian, cepat dan tepat dalam menghadapi permintaan, pertanyaan, keluhan, dan masalah dari pelanggan yang merefleksikan persiapan perusahaan/instansi sebelum memberikan pelayanan. Mengetahui tujuan pengobatan dan tindakan perawatan yang diberikan termasuk dalam permintaan dan pertanyaan sehingga karyawan/staf dapat mempersiapkan jawaban dan dapat membantu pelanggan dalam menjelaskan kebutuhan keluarga dalam mengetahui tujuan pengobatan dan tindakan perawatan yang diberikan. Menurut peneliti hal ini sangat penting, dengan mengetahui tujuan pengobatan dan tindakan dari staff kesehatan keluarga dapat menumbuhkan rasa percaya serta mempermudah staff kesehatan untuk melakukan tindakan pada pasien.

\section{Kebutuhan keluarga akan informasi}

Selanjutnya kebutuhan keluarga terakhir terkait informasi untuk "Mengetahui 
kondisi pasien yang sebenarnya" menyatakan dari 21 responden terdapat $66.7 \%$ yang menyatakan sangat penting. Penelitian serupa yang dilakukan oleh Molter \& Leske, (1995) menyatakan bahwa "To know specific facts concerning the patient's progress" terdapat 31 responden menyatakan sangat penting dari 40 responden. Sejalan dengan penelitian oleh Saputra dan Utami (2018), dari 54 responden bahwa dari $66.1 \%$ menyatakan bahwa kebutuhan itu sangat penting untuk kebutuhan " mengetahui data-data spesifik yang berhubungan dengan perkembangan pasien". Penelitian yang dilakukan Gundo et al., (2014), terdapat 62 responden yang berpartisipasi menyatakan "To know specific facts concerning the patient's progress" sebagai kebutuhan yang menepati urutan ke-13 dari 45 variabel yang tersedia dengan mean 3.58 yang menyatakan kebutuhan tersebut penting.

Menurut UU No. 44 tahun 2009 , pasien memiliki hak mendapat informasi yang meliputi diagnosis dan tata cara tindakan medis, tujuan tindakan medis, alternatif tindakan, risiko dan komplikasi yang mungkin terjadi, dan prognosis terhadap tindakan yang dilakukan serta perkiraan biaya pengobatan, memperoleh layanan yang manusiawi, adil, jujur, dan tanpa diskriminasi. Kewajiban rumah sakit ialah memberikan informasi yang benar, jelas dan jujur mengenai hak dan kewajiban pasien. kebutuhan tersebut merupakan hal yang penting, dengan mengetahui kondisi pasien yang sebenarnya keluarga dapat memberikan dukungan kepada pasien serta dapat mengambilan keputusan yang paling tepat menurut keluarga atas tindakan selanjutnya kepada pasien atas pilihan yang diberikan staff kesehatan.

\section{Kebutuhan keluarga akan dukungan mental keluarga}

Berdasarkan hasil penelitian diatas untuk dukungan mental keluarga, kebutuhan untuk "Mendapatkan dukungan antar keluarga" didapatkan dari 21 responden terdapat $71.4 \%$ yang menyatakan kebutuhan tersebut sangat penting. Sejalan dengan penelitian yang dilakukan oleh Molter \& Leske, (1995) menyatakan bahwa "To have friends nearby for support" terdapat 34 responden menyatakan sangat penting dari 40 responden. Berbeda dengan penelitian yang dilakukan oleh Dharmalingam et al., (2016), terdapat 60 responden yang berpartisipasi menyatakan "To have friends nearby for support" sebagai kebutuhan yang menepati urutan ke-28 dari 45 variabel yang tersedia dengan mean 3.10 yang berarti kebutuhan tersebut penting tetapi tidak menjadi prioritas.

Menurut Morton, Fontaine, Hudak, dan Gallo (1997), mendapat dukungan antar sesama anggota keluarga merupakan hal penting. Berdasarkan hal tersebut, menurut Herawati \& Fithriyani, (2018), keluarga yang menunggu pasien diruang ICU akan lebih mementingkan keadaan pasien sehingga pasien rentan akan kondisi negatif seperti sakit serta kecemasan yang berlebihan, tetapi dengan dukungan keluarga lainnya maka diharapkan dapat mengurangi efek negatif tersebut dan dapat berbagi beban bersama.

\section{Kebutuhan keluarga akan kenyamanan}

Perolehan hasil penelitian kebutuhan keluarga untuk "Tersedia kamar mandi dekat ruang tunggu" didapatkan dari 21 responden terdapat $42.9 \%$ menyatakan kebutuhan tersebut penting dan sangat penting. Sejalan dengan penelitian yang 
dilakukan oleh Saputra dan Utami (2018), dari 54 responden menyatakan bahwa dari $57.3 \%$ menyatakan penting untuk poin kebutuhan "terdapat toilet didekat ruang tunggu". Hasil yang sama didapat dari penelitian yang dilakuan oleh Molter \& Leske, (1995) menyatakan bahwa "To have a bathroom near the waiting room" terdapat 25 responden menyatakan sangat penting dari 40 responden lainnya.

Hasil observasi di CCU, kamar mandi berada diruang tunggu keluarga dengan keadaan terawat, adanya toilet di ruang tunggu dapat mempermudah keluarga untuk tetap berada diruang tunggu sehingga keluarga dapat secara berkelanjutan menunggu informasi dari staf rumah sakit. Sedangkan pada penelitian yang dilakukan oleh Jacob et al., (2016), disalah satu rumah ssakit di Amerika tentang kebutuhan keluarga pasien dengan kunjungan berkelanjutan menyatakan keluhan tentang lingkungan rumah sakit yang berbunyi kamar mandi terlalu jauh dari ruang ICU, seharusnya keluarga diperbolehkan untuk menggunakan kamar mandi pasien atau kamar mandi lebih dekat dengan ruang ICU serta kamar mandi yang berada di rumah sakit tidak bersih, dengan pernyataan ini dapat dilihat bahwa kamar mandi yang dekat ruang tunggu dan bersih merupakan hal yang penting.

Kebutuhan keluarga terkait kenyamanan keluarga ialah untuk "Tersedia ruang tunggu didekat ruang intensif" didapatkan dari 32 responden terdapat 42.9\% menyatakan kebutuhan tersebut penting dan sangat penting. Hasil yang sama didapat dari penelitian yang dilakuan oleh Molter \& Leske, (1995) menyatakan bahwa "To have the waiting room near the patient" terdapat 34 menyatakan sangat penting dari 40 responden lainnya. Sedangakan penelitian yang dilakukan oleh Dharmalingam et al., (2016), terdapat 60 responden yang berpartisipasi menyatakan "To have the waiting room near the patient" sebagai kebutuhan yang menepati urutan ke-15 dari 45 variabel yang tersedia dengan mean 3.57 yang menyatakan kebutuhan tersebut penting. Sejalan dengan penelitian yang dilakukan oleh Saputra dan Utami (2018), dari 54 responden menyatakan bahwa dari $40.7 \%$ menyatakan penting untuk poin kebutuhan "terdapat ruang unggu didekat pasien".

Menurut Kementrian Kesehatan RI (2011), tentang saran dan prasarana bahwa didekat ruang ICU tersedia ruang tunggu keluarga pasien. Kebutuhan ini merupakan hal yang sangat penting dengan adanya ruang tunggu didekat ICU dapat mempermudah keluarga dan staf medis untuk berkomunikasi dan menyampaikan informasi serta memperdekat keluarga dengan pasien.

\section{Kebutuhan keluarga akan kedekatan}

Kebutuhan keluarga berikutnya masih terkait dengan kedekatan ialah untuk "Mengunjungi pasien diruang intensif (CCU) bersama salah satu kerabat" didapatkan dari 21 responden terdapat $38.1 \%$ menyatakan kebutuhan tersebut sangat penting. Sejalan dengan penelitian yang dilakukan oleh Saputra dan Utami (2018), dari 54 responden menyatakan bahwa dari $51.9 \%$ responden menyatakan bahwa kebutuhan itu penting untuk poin kebutuhan "terdapat orang lain yang mendampingi saat berkunjung ke ICU".

Hasil yang berbeda didapat dari penelitian yang dilakuan oleh Molter dan Leske (1995) menyatakan bahwa 
"To have another person with you when visiting the critical care unit" terdapat 32 responden menyatakan tidak penting, dari 40 responden yang berpartisipasi. Sedangkan pada penelitian Gundo et al., (2014), terdapat 62 responden yang berpartisipasi menyatakan "To have another person with you when visiting the critical care unit" sebagai kebutuhan yang hanya menepati urutan ke-33 dari 45 variabel yang tersedia dengan mean 3.02 yang berarti kebutuhan keluarga tersebut penting tetapi tidak menjadi prioritas.

Menurut AACN (2019), diruang perawatan intensif dewasa keluarga dan teman lainnya disambut 24 jam disambut berdasarkan pilihan pasien. Kebutuhan tersebut merupakan hal penting karena dengan berkunjung bersama kerabat memberikan pasien rasa kepedulian dari keluarga serta keluarga yang menunggu pasien mendapatkan dukungan serta rasa kedekatan dengan keluarga sebagai dukungan.

\section{SIMPULAN}

Berdasarkan penelitian yang telah dilakukan tentang gambaran kebutuhan pasien Critical care unit (CCU) yang dilakukan di Rumah Sakit Umum Daerah (RSUD) Arifin Achmad provinsi Riau dapat disimpulkan berdasarkan data karakteristik responden diatas dapat dilihat dari 21 responden dalam penelitan ini didapatkan sebagian besar reponden berjenis kelamin laki-laki, dengan jumlah usia terbanyak pada kategori usia dewasa awal 26-35 tahun, hubungan dengan pasien sebagian besar sebagai saudara, pengalaman CCU sebelumnya sebagian besar tidak memiliki pengalaman di $\mathrm{CCU}$, dan tempat tinggal responden sebagian besar tinggal di kota Pekanbaru. Serta berdasarkan hasil penelitian mengenai gambaran kebutuhan pasien Critical care unit (CCU) diperoleh hasil bahwa kebutuhan keluarga yang paling dibutuhkan keluarga pada lima kebutuhan keluarga di CCU didapat kebutuhan keluarga akan jaminan pelayanan sebagaian besar responden menyatakan sangat penting untuk "Mengetahui tujuan pengobatan dan tindakan perawatan yang diberikan", pada kebutuhan keluarga akan infromasi sebagian besar responden menyatakan sangat penting untuk "Mengetahui kondisi pasien yang sebenarnya", dari hasil kebutuhan keluarga akan dukungan mental keluarga sebagian besar responden menyatakan sangat penting untuk "Mendapatkan dukungan antar keluarga", pada perolehan hasil kebutuhan keluarga akan kenyamanan sebagian besar responden menyatakan penting dan sangat penting untuk "Dapat mengungkapkan setiap perasaan yang dirasakan", "Tersedia kamar mandi dekat ruang tunggu", dan pada kebutuhan keluarga kebutuhan keluarga akan kedekatan sebagian besar responden menyatakan sangat penting untuk "Mengunjungi pasien di ruang intensif (CCU) bersama salah satu kerabat".

\section{DAFTAR PUSTAKA}

ACCN Practice Alert. (2019). Family Visitation in the Adult Intensive Care Unit. American Association of CriticalCare Nurses (2019) 36(1). DOI: http://dx.doi.org/10.4037/ccn2016677

Atika, \& Halimuddin. (2018). Kebutuhan Keluarga Pasien Di Unit Perawatan Intensif. Jim Fkep, III(3), 315-321. 
Bustami. (2011). Penjaminan mutu pelayanan kesehatan \& akseptabilitasnya. Jakarta : Erlangga.

Dewan Perwakilan Rakyat Republik Indonesia \& Presiden Republik Indonesia. (2009). UU No. 44 Tahun 2009 tentang rumah sakit (hal. 1-40). http://www.depkes.go.id

Effendi, F., \& Makhfudli. (2009). Keperawatan Kesehatan Komunitas: Teori dan Praktek Dalam Keperawatan. Jakarta: Salemba medika.

Irwanto. (2002). Psikologi umum : Buku panduan mahasiswa. Jakarta : PT Prenhallindo.

Kabey, A.,W., Kapend, A., K., L., Kilembe, M., A. (2017). Epidemiological Profile of ICU Mortality at the Lubumbashi University Teaching Hospital, Democratic Republic of the Congo. International Journal of Science and Research (IJSR), 6(9), 2029-2034. https://doi.org/10.21275/ART20177010

Dharmalingam, T. K., Kamaluddin, M. R., Hassan, S. K., \& Zaini, R. H. M. (2016). The needs of Malaysian family members of critically ill patients treated in Intensive Care Unit, Hospital Universiti Sains Malaysia. Malaysian Journal of Medicine and Health Sciences, 12(2), 9-17.

Fauziah, S., \& Latipun. (2016). Hubungan Dukungan Keluarga dan Keberfungsian Sosial pada Pasien Skizofrenia Rawat Jalan. Jurnal Ilmiah Psikologi Terapan, 04(02), 140-160.

Gundo, R., Feggie Bodole, F., Lengu, E., \& Alfred Maluwa, A. (2014). Comparison of Nurses' and Families' Perception of Family Needs in Critical Care Unit at Referral Hospitals in Malawi. Open Journal of Nursing,
04(04),

$312-320$. https://doi.org/10.4236/ojn.2014.44036

Hardisman. (2008). Lama Rawatan Dan Mortalitas Pasien Intensive Care Unit (ICU) RS Dr. Djamil Padang Ditinjau dari beberapa Aspek. Majalah Kedokteran Andalas, 32(2), 142-150.

Herawati, M., \& Fithriyani, F. (2018). Pengalaman Keluarga Menghadapi Hospitalisasi Pasien Kritis Di Ruang Icu Rs Dr. Bratanata Jambi. Jurnal Akademika Baiturrahim Jambi, 7(1), 33. https://doi.org/10.36565/jab.v7i1.63

Jacob, B. M., Horton, C., Rance-ashley, S., Field, T., Patterson, R., Johnson, C., Saunders, H., Shelton, T., Miller, J., \& Frobos, C. (2016). Ajcc American Journal Of Critical Care . 25(2), 118125.

Kementrian Kesehatan RI. (2011). Petunjuk Teknis Penyelengggaraan Pelayanan Intensive Care Unit (ICU) di Rumah Sakit. Jakarta : Direktur Jedral Bina Upaya Kesehatan. Nomor : HK.02.04/I/1966/11.

Lukmanulhakim, \& Firdaus, W. (2018). Pemenuhan kebutuhan keluarga pasien kritis di ruang intensive care unit (ICU) RSUD Dr. Dradjat Prawiranegara Serang. Jurnal Ilmu Keperawatan Dan Kebidanan, 09(1), 104-110. https://doi.org/10.4037/ajcc2011243

Molter, N. C., \& Leske, J. S. (1995). Critical Care Family Needs Inventory (CCFNI). January 1995, 4 p. https://doi.org/10.1037/t37619-000

Morton, G. P., Fontaine, D., Hudak, C. M., \& Gallo, B. M. (1997). Keperawatan Kritis : Pendekatan Asuhan Kritis (Edisi 6, Volume 1). Jakarta : EGC. 
Morton, G. P., Fontaine, D., Hudak, C. M., \& Gallo, B. M. (2013). Keperawatan Kritis : Pendekatan Asuhan Kritis (Edisi 8, Volume 1). Jakarta : EGC.

Nasir, A., \& Muhith A. (2011). Dasardasar keperawatan jiwa : Pengantar dan teori. Jakarta : Selembah Medika.

Rosmalawati, K., N., W., D. (2016). Kebutuhan dasar manusia I. Jakarta Selatan : Pusdik SDM kesehatan.

Saam, Z., \& Wahyuni, S. (2014). Psikologi keperawatan. Jakarta : PT Raja Grafindo Persada.

Saputra, G. H., \& Utami, R. S. (2015). Gambaran kebutuhan keluarga pasien kritis di intensive care unit. Proceeding Seminar Ilmia Nasional Keperawatan (2015) 3:364-375. ISBN : 9786027279506

Shorofi, S. A., Jannati, Y., Moghaddam, H. H., \& Chariti, J. Y. (2016). Psychosocial needs of families of intensive care patients: Perceptions of nurses and families. Nigerian Medical jurnal (2016) 57(1): 10-18. DOI: $10.4103 / 0300-1652.180557$

Silva, N. R., Fortunatti, C. P., Muñoz, Y. M., \& Rojas, M. A. (2017). The needs of the relatives in the adult intensive care unit: cultural adaptation and psychometric properties of the Chilean-Spanish version of the Critical Care Family Needs Inventory. Journal of Critical Care, 42(November 2017), 406-407. https://doi.org/10.1016/j.jcrc.2017.09.1 15 